\title{
Fostering Halal and Thoyyibah Food in Early Childhood Education
}

\author{
1 Wahju Dyah Laksmi Wardhani, 2Sawitri Komarayanti, ${ }^{3}$ Tri Endang Jatmikowati, \\ ${ }^{4}$ Misyana \\ 1,2,3,4 Universitas Muhammadiyah Jember, Jember, Indonesia \\ 1dyahlaksmi_paud@unmuhjember.ac.id, 2komarayantisawitri@yahoo.com, \\ 3triendang@unmuhjember.ac.id, ${ }^{4}$ misyana@unmuhjember.ac.id
}

\begin{tabular}{|c|c|}
\hline Article Info & bstract \\
\hline $\begin{array}{l}\text { Article History } \\
\text { Received: July 12, } 2018 \\
\text { Accepted: September 30, } \\
2018\end{array}$ & \multirow{2}{*}{$\begin{array}{l}\text { This study aims to construct the idea or thought regarding the importance of } \\
\text { introducing halal and good food through early childhood education. Little } \\
\text { children, including those of Muslims, generally do not have adequate } \\
\text { knowledge about halal and good food according to Islamic jurisprudence } \\
\text { (fiqh Islam). Children's pattern of consumption, types of food they eat, and } \\
\text { the ingredients of food cooked for them are generally determined by their } \\
\text { parents or influenced by their social and cultural environments. By means of } \\
\text { early childhood education, the knowledge of halal and good food is } \\
\text { introduced earlier to the children in gradual steps in line with their age and } \\
\text { developmental phases. Through constructivist-interpretive approach, this } \\
\text { study is intended to analyze the importance of introducing, disseminating, } \\
\text { and internalizing the knowledge, attitude, and skill about halal and good } \\
\text { food to the children. The study also provides the children with graded lessons } \\
\text { to identify halal and good food. The ultimate end the analysis is expected to } \\
\text { yield integrated lessons on halal and good food within the curriculum of } \\
\text { early childhood education. }\end{array}$} \\
\hline $\begin{array}{l}\text { Keywords } \\
\text { Early Childhood; Halal and } \\
\text { Good Food; Education; } \\
\text { Education }\end{array}$ & \\
\hline $\begin{array}{l}\text { Support by: } \\
\text { doi) Crossref }\end{array}$ & \\
\hline
\end{tabular}

\section{INTRODUCTION}

Children are unique and, generally,different in various aspects from those in teenagers and adults. This is owing to the process of physically developing and cognitively, psychologically, and linguistically improving in children, but are not reaching the abstract conceptual understanding, yet. At their very young age, children see and observe a concept from concrete points of view, thus construct their knowledge following the construct of prior knowledge. This particular process will develop through interactions and learning experiences acquired by children from their environment. A well-structured childhood education out of family environment is crucial in facilitating children to sharpen their development.

The public awareness on the importance of early construction of learning experiences was started as the Government proclaimed the National Education System in Indonesia. This trend has been marked by the higher interest of society to deliver their 2-5 years old children to schools of early childhood education, known as ECE (Early Childhood Education).Since then, the development of ECE has been more rapid, that since 2003 a school model for ECE has been developed in accordance with the Act no. 20 of 2003 under National Education System. It is recorded that in 201688.831 kindergartens, a formal category institution of ECE, were registered in Indonesia. This number has increased from the record of 2009 that the total number of kindergartens in Indonesia was 68.484 schools. In other words, in less than a decade, there have been more than 20.000 schools of ECE of the formal category started. 
In 2013, the Indonesian's Government has established a new curriculum, better known as Curriculum 2013, through the issuance of the Regulation of Ministry of Education and Culture no 146 of 2014. The Curriculum 2013 brings along a new approach to a more innovative teaching, which is scientific approach. Meanwhile, the Curriculum 2013 for Early Childhood Education (ECE) was also formulated but issued a little later, for it was harder to find a form which best suits various learning models to be applied in Indonesian's schools. The Curriculum 2013 for ECE is aimed for learners of 4 to 6 years old, or students of kindergartens (of the formal category). Despite this, along with the issuance of the Accomplishment Standard of Child Development (ASCD) through the Regulation of Ministry of Education and Culture no 137 of 2014, ECE schools of the non formal category have a clarified reference on minimal standard of development aspect which can be taught through the education.

Some contents of basic competences to be taught for learners of 4 to 6 years old, in both ASCD and the Curriculum 13 ECE are related to familiarizing children with their religion, healthy lifestyle, leading them to showing curiosity, and applying knowledge or experience in a new context. Such learning contents will then become the guiding path for showing the importance of constructing child's knowledge on religion's rules, especially those of Islam. Substantively, Islam has taught about simple habituations, that can be trained so early that can help build child's knowledge about religion's rules earlier.

In some cases, children are considered not independent enough to make their own decisions, and take whatever chosen by their parents instead. In other cases, their choices are approved by their parents. Such phenomena will be observable when children choose the kinds of food they want to have. Furthermore, some evidences indicate that children are given no authority to decide which food they want. On the contrary, other evidences imply that parents hand over the rights of making choices to their children. These two kinds of evidences would actually not matter if the available choices of food are all halal and thoyyib. However, such evidences are sometimes not well considered, including the probability that children make their choices with very limited understanding of fiqh.

Halal food, as opposed to haram food, has been defined in Al-Baqarah:168, AlMaidah: 88, Al-Baqarah: 172, An-Nahl: 144and other chapters as well. These Quran verses have clearly defined what kinds of food and food materials allowed by Allah for human beings to consume or following what conditions they may be consumed. The matter of knowing kinds of food and food materials has been considered important not only by countries with the most Muslim citizens but also by those with minimal number of Muslim citizens. Studies by Yousaf and Fan (2018), Demirci, Jan and Wallace (2016), Oktadiana, et al., (2016), Jamal and Sharifuddin (2014), Ambali and Bakar (2042), on halal certification that is regarded for even non-Muslims as a guarantee for healthy, quality, and safe for consumption food.

Halal certification is a trustworthy label for Muslims on products worth consumption, following the teaching of Islam. Furthermore, this certificate indicates that a product on which this label attached contains no haram materials, i.e. materials made of pork which are usually added to mixture of other materials, like thickener, flavor enhancer, tenderizer, or color enhancer. Moreover, studies on the importance of certifying halal products have been conducted by Mohtar, et al., (2014), Zulfakar, et al., (2014), Afifi, et al.,(2014), and Che Din and Daud (2014).Food materials taken from pig are usually known by bovine or porcine or other names, as such information was found 
in many studies like Sulthana, et al., (2018), Amqizal (2017), Zhao (2017), and Shabbania (2015).

Besides consuming halal food, Muslim should also consume thoyyibah food. Thoyyibah means quality, delicious, and good for health. Practically, such food should have clean substances, not expired and not accidently interrupted by najis that may be harmful for one's health and mind. A study by Karrebaek (2014) on the analysis of child's language registers about food has found that children of Muslim community are informed about the concept of halal food which can be consumed. This indicates that since their early age, children have been introduced to food they can consume, and that the Muslim community has introduced the term halal related to health as a partial concept of thoyyibah food.

Meanwhile, for Muslim parents who wish to have their children to be solih/solihah, always curious, spontaneous, in the child's developmental stage (in which they grow their characters and learning potentials) parents should start teaching and cultivating the feeling of fear to God to their children. Among all lessons which can be taught to children is to introduce halal and haram. In introducing Muslim children to halal and thoyyibah food, appropriate learning strategies should be prepared. Such teaching of halal and thoyyibah food has become more urgent as more products of snacks, well packaged or not, with doubtful quality have gone on sales in the markets; they are doubtful as it is not clear what materials contained in the products, what quality carried along, as well as how they will affect the child's health in both short and long term effect. This concern has been previously uttered by Allirot, Maiz and Urdaneta (2017) and Bent, et al., (2016), while the child protection against addictive materials is studied by Folkvord and Van't Riet (2018) and McBride (2017).

The present article attempts to sketch out the theoretical framework on reinforcing learning of halal and thoyyibah food for learners of Early Childhood Education within the age range of 4 to 6 years old. This framework will further be necessary as a stepping stone for developing integrated learning models by strengthening the teaching supplements thus aiming to have better implementation which will result in accurate conceptual understanding on halal and thoyyibah food in the level of Early Childhood Education. Introducing halal and thoyyibah food through ECE schools is constructed based on the understanding that teachers of ECE are an agent of social change whose educational background is more measurable than those of the children's parents who are more heterogeneous. Besides, parents, especially those with relatively low educational background, have entrusted their children to the teachers believing that everything taught by teachers to their children are for the sake of their children.

\section{METHOD}

The present study used constructivist-interpretivistic approach; a combinedapproach in qualitative research. The latter approach, the interpretivistic, according to Schwandt (Denzin and Lincoln, 2009; 149), stands on the assumption that social reality as seen from empirical point of view has lost its inter-subjective meanings, therefore it is an approach that attempts to reflect behaviors among society into language and descriptions. On the other hand, as seen from the constructivist approach the present study would describe the processes of creating, association, defending, and modifying meanings upon learning objectives, teaching methods and learning contents for introducing halal and thoyyibah food to young learners. Further, the study of intersubjective meanings is important to narratively describe the theoretical analysis about the importance of introducing halal and thoyyibah food to children or young 
learners by considering the child developmental stage and child's learning characteristics.

The constructivist approach in educational research is described by Eisner (Denzin and Lincoln, 2009; 163) to understand the quality of learning experiences, thus later may change perceptions into representation by depicting, interpreting intersubjective meanings received from learning experiences. Moreover, narratively the study would reconstruct or transform perceptions critically so that learning experiences will emerge again in readers. The present article, therefore, expect to make changes in reader's perception about halal and thoyyibah food introduced to young learners and will later contribute to the meaningful learning experiences for the future.

\section{RESULT}

Introducing healthy lifestyle to young learners, i.e. taking a shower, brushing teeth, sleeping regularly, having healthy diet, has been a regular teaching plan of a teacher of ECE. Other programs like going to a dentist, body weighing, and having lunch together are forms of efforts from teachers and schools to reinforce child's knowledge and attitude to start caring for their own health. These are examples of structuredintegrated activities which aim to give meaningful learning experiences for children that may help construct child's physical activities, cognitive, and social skills as fundamentals to reconstruct new knowledge that will help build a healthier self concept.

Although the aforementioned activities have been implemented in ECE schools, not all ECE schools agree to consider them as integrated learning experiences which can help children to regulate themselves and their prior knowledge about the importance of healthy living. It is not impossible that the effort to introduce this importance has been done, however it might be limited to introducing it as knowledge, not supported by integrated learning patterns. It could be caused by minimal support from parents to succeed the aforementioned activities, teacher's limited knowledge about the appropriate teaching and learning process for children, or schools are not yet wellfacilitated.

In the theoretical framework for early childhood learning, providing knowledge and meaningful learning experiences about healthy living and its practices are supposed to be given to children in a concrete manner, knowing that children have limited capacity to understand verbal messages. Moreover, children should understand the importance of healthy lifestyle and ways to maintain their health and make themselves accustomed to it. They need to know and be informed about healthy food and body, preventing illness, or relations between healthy food, healthy body, and attempts to prevent themselves from illness, as a result of thinking critically; thus it will become a new knowledge input.

Furthermore, it is vital to understand that nutrition consumed by children will have effects on their behaviors. Healthy diet will help children to be better manageable, more concentrated, yet active. The attempt to introduce shapes, kinds, and materials of food or healthy food products is actually an integral part of building the concept of healthy and prosperous living in the future, by making use of stimulation potential in child's developmental aspect. In fact, it will be a lot easier to exemplify since children naturally learn through concrete things and by supporting it with optimal support to child's cognitive development potential in their golden age, this critical lesson of healthy living will be effortlessly internalized by children. 
Following the above mentioned point, one of the ways to introduce healthy nutrition is through introducing halal and thoyyibah food. It is true that the topic of halal and thoyyibah food is mostly thought of only limited to food allowed to consume for Muslims. However, this far, it has been known that the halal quality of a food product also becomes a quality guarantee that a certain food product is worth consuming. In fact, this topic is not limited to only Muslim communities, but has recently been considered by many countries as well. Attached to halal quality of food is thoyyib, which is constructed upon the system and process of a product to be attained and produced. From Islam point of view, thoyyib is defined as the process of earning money that will later be used for purchasing food materials or products for consumption purposes. Meanwhile, in a more globalized thought, thoyyib can be described as a system which assure quality, starting from the initial form of the food through processing and finally packaging to be purchased by customers in the market.

In Islam, food variety for consumption is restrained by the concept of halal and haram. While halal is always attached by the concept of thoyyib, haram is explained as something forbidden to be consumed. Several verses of the Quran, mention kinds of food that are allowed to be consumed with no restrictions by human beings, such as livestock (cows, goats, and camels), fish, fruits, honey, and plants. Islam also strictly defines food of the haram category (not to be consumed), like pigs, dead animals, and blood or alcoholic beverages. In other words, any kinds of food or processed food that contain materials of haram category are not to be eaten or better avoided. Should we be in a condition with no other choices of food, however, such food containing haram materials can be consumed but in a very limited amount and not to be excessive.

The definition of halal can be introduced to children by constructing child's knowledge about halal and thoyyib food by following a verse in the Quran, Surah Al Maidah: 4 that is translated as follows: "They ask you what is lawful for them. Say 'Lawful unto you are foods (the good things) and those (beasts and birds of prey) which you have trained as hounds, training and teaching them (to catch) in the manner as directed to you by Allah. So eat of what they catch for you, but pronounce the Name of Allah over it andhave Taqwa of Allah. Verily, Allah is swift in reckoning". Therefore, it can be similarly understood that halal food is sure thoyyib as well, while the definition of halal and haram is also mentioned in other verses in the Quran besides that of $\mathrm{Al}$ Maidah.

The construct of thoyyib food definition can have a wider scope as it is to adjust with the knowledge construct of young learners. The concept of thoyyib or good to be introduced to children can be introduced by the variety of products that can be consumed, how to get them, how they are processed, and how they can be useful for children. This concept can also be reflected in the forms of balanced diet; balance is defined as the appropriate amount or balance composition of the food variety.

Introducing food variety to children can begin from the origin of the food; either it is made from animal or plant, additives or vitamin contents and source of nutrition for body. It is also necessary for children to know kinds of halal and thoyyib food to be consumed in well-proportion, like the substitute of rice as source of carbohydrate that is good to consume, vegetable, fruits, proteins from different sources and/or snacks as food variation. Besides, children should also be informed about different composition and portion of meals at daily main meal and at snacking time or at certain meal time.

Secondly, the concept of thoyyib can be taught to children by telling them about how the food is obtained. Something good (thoyyib) is that obtained as gift or blessing from God the Wealthy. Then, the food purchased or obtained as gift or blessing from Allah is 
believed to bring goodness to those who enjoy it. Meanwhile, the way or process to obtain the product is related to how the food material is processed, like how to butcher animals, catch fish, plant and grow the plant. Specifically to animals whose meat is prepared, the process of butchery must begin by saying the name of Allah and using a sharp knife which is meant not to hurt animals. Moreover, using excessive chemical fertilizer for growing plant is better replaced by using compost that is more environment-friendly. This way, children will know how a product is obtained; whether it is good or not, therefore they know if it will not decrease the value of thoyyib from a food, despite its halal quality.

The third concept of thoyyib is food processing. It is important for children to know about different methods of healthy food processing. The variety of food processing that can be taught to children may include frying, boiling, burning or steaming, each of which consequently will result in different textures, tastes, or colors of the materials processed. Other methods can also be taught to children, like preserving or processing materials in larger amount and into which are added some other materials, either as preservative or taste or texture enhancer.

Next, the fourth thoyyib concept is related to the use of halal and thoyyib food for children for helping their developmental stage. Teaching this concept should be related not only to the increase in body weight, height, and endurance against diseases but also to differences in child's development thus they will not grow themselves as picky eaters. In most cases, children are not given rights to pick kinds of food, food composition or how to process food in their preference. They receive what is given to them by their parents. Even worse, parents hardly care about the meaning of thoyyib, especially on the benefits of the food consumed to their children following their needs and balance of their development.

Therefore, socializing the use or benefits of food for children to parents is important as they play the role as decision maker and food provider for their children. Sorte and Daeschel (in Henniger, 2013; 342) identify the pleasure of consuming fast-served food with high fat and glucose, and coupled with aggressive advertisement by its company, become the ultimate cause for rapid increase in body weight and obesity in children. One of the attempts to balance out such imbalance nutrition is by providing understanding through teaching and learning process in ECE about choosing the good food.

The strategy for introducing halal and thoyyib food for children in ECE schools PAUD can be performed integratedly with different themes; existing or newly created subthemes, like halal animals, halal and thoyyib food, halal and haram food or food fiqh. A well-structured teaching can be supported by other activities like parenting and innovative teaching methods assumed to trigger the emergence of child's knowledge and skills about halal and thoyyib food.

The curriculum content for young learners within the age range of 4 go 6 years old about good food in Standard of Child Development Performance is not specifically mentioned; even the development objective of the content related to the food functions is not specifically described in the curriculum. Therefore, the content development design on halal and thoyyib food is explained in the following.

1. Introducing laws of halal and haram food

Children should start building critical understanding on the applicable laws of allowed food in Islam, although the laws can also be implemented to other religions. By halal labeling, people will be certain about the good processing standard of the product, starting from its raw materials until it is ready to 
consume. Therefore, children should also be introduced to the halal label on product packages.

2. Identifying variety of halal and thoyyib food

Children should be taught how to identify halal and thoyyib food. Food materials made from animals, for instance, should not be at all included into haram category or be thought the same as that of pigs, dead animals, blood or alcoholic beverages. Food of halal and thoyyib category includes livestock animals which have been butchered by saying the name of Allah and using tools which will not hurt the animals. On the contrary, teaching how to identify haram food as defined by the Quran by showing kinds or materials of food that are forbidden to be consumed, will enrich child's knowledge and train their critical thinking skills of food variety.

3. Introducing halal and thoyyib food as real food

Pollan (Henniger, 2013; 343) argue that many parents provide meals or follow what their children want that are already enhanced with flavor or color enhancer without thinking further that this would lead to the children's failure to recognize the real taste of certain food. Healthy food is that with unique taste, aside from the use of pinch of salt and sugar. Such food could also help keep children from being addicted to certain product which may not be good for their health in the future.

4. Providing learning activities that make children actively involved

Making children actively involved in certain activities like cooking, shopping, and having meals will construct their attitude, knowledge, and psychomotor for analyzing food materials, kinds of food, and food processing that make halal and thoyyib food. This activity will be more meaningful to if parents are involved, thus the same perception between parents and their children about halal and thoyyib food can be built.

\section{CONCLUTION}

Constructing child's attitude, knowledge, and psychomotor skills in recognizing and analyzing halal and thoyyib food animals in ECE schools requires well-prepared teaching designs. The first step is to familiarize children with fiqh of halal and haram food for young learners following the definitions as stated by the Quran and Hadith is a certainty because it will become the basic knowledge that keeps children in the right way of Islam. Next, such introduction should be built upon needs analysis and interest by considering the child's chances to obtain accurate information for task illustration.

The learning strategy proposed to introduce halal and thoyyib food to children are designed not only by integrated stimulation in every development aspect within the theme or sub-themes but also by parents involvement in order to synchronize perceptions of halal and thoyyib food between parents and their children. Thus, an integrative teaching method which actively involves parents is highly required.

\section{REFERENCE}

[1] Ahmad, A.N., Rahman, R.A., Othman, M., et al. 2016. Critical success factors affecting the implementation of halal food management systems: Perspective of halal executives, consultants and auditors. Food Control. DOI: 10.1016/j.foodcont.2016.11.031

[2] Ali, M.H. and Suleiman, N. 2016 Sustainable Food Production: Insights of Malaysian Halal Small and Medium Sized Enterprises. Intern. Journal of Production Economics. DOI: http://dx.doi.org/10.1016/i.ijpe.2016.06.003 
[3] Allirot. X., Maiz. E., Urdaneta. E., 2017. Shopping for food with children: A strategy for directing their choices toward novel foods containing vegetables. Appetite. Vol. 120. $\mathrm{P}$ 287 -296. DOI: https://doi.org/10.1016/j.appet.2017.09.008

[4] Ambali, A.R. and Bakar, A.N. 2014. People's Awareness on Halal Foods and Products: Potential Issues for Policy-Makers. Procedia - Social and Behavioral Sciences 121 (3 $-25)$

[5] Aziza, N.A., Majdina, H., Hassan, H., et al. 2014. Assessment of the Halal Status of Respiratory Pharmaceutical Products in a Hospital. Proceedia-Social and Behavioral Sciences 121 (158-165)

[6] Bent, M.S., Mikkelsen, E., Lyytikäinend, A., Ojansiv P., et al. 2016. Future for food education of children. Future, Vol. 83. October 2016. P 15 - 23

[7] Demirci, M.N., Soon, J.M., Wallace, C.A. 2016. Positioning food safety in Halal assurance. Food Control. http://dx.doi.org/10.1016/j.jbusres.2014.09.020

[8] Florack, A., Haasova, S., Hirschauer, S., Serfas, B.G. 2018. Playing with food: The effects of food pre-exposure on consumption in young children. Physiology and Behavior volume 195 (pages 76 - 81). DOI: http://dx.doi.org/10.1016/j.jbusres.2014.09.020

[9] Folkvord, F. and van 't Riet, J., 2018. The persuasive effect of advergames promoting unhealthy foods among children: $A$ meta-analysis. Appetite. DOI: https://doi.org/10.1016/i.appet.2018.07.020

[10] Henniger, M.L. 2013. Teaching Young Children: an Introduction, Boston: Pearson

[11] Jamal, A., Sharifuddin. J., 2014. Perceived value and perceived usefulness of halal labeling: The role of religion and culture. Journal of Business Research. DOI: http://dx.doi.org/10.1016/j.jbusres.2014.09.020

[12] Mohtara, N.M, Amirnordin, N.A., Haron, H, Dr. 2014. Ayamas Food Corporation Sdn. Bhd: A Study on the Factors of Consumer Behaviour towards Halal Product Selection. Proceedia-Social and Behavioral Sciences 121(166-185).

[13] McBride, D. L., 2018. Safety Concerns about Food Additives and Children's Health. Journal of Pediatric Nursing. DOI: https://doi.org/10.1016/i.pedn.2018.09.008

[14] Shabani, H., Mehdizadeh. M., Mohammad, S., Ehsan, M. 2015. Analytical Methods Halal authenticity of gelatin using species-specific PCR. Food Chemistry. DOI: http://dx.doi.org/10.1016/j.jbusres.2014.09.020

[15] SifKarrebæk, M., 2014. Rye bread and halal: Enregisterment of food practices in the primary classroom. Language and Communication. Vol. 34. DOI: https://doi.org/10.1016/j.langcom.2013.08.002

[16] Sultan, S., Hossain, M., Zaiduld., Ali, E., 2018. Multiplex PCR to discriminate bovine, porcine, and fish DNA in gelatin and confectionery products. DOI: http://dx.doi.org/10.1016/j.jbusres.2014.09.020

[17] Zulfakar, M.H., Anuar, M.M., Ab Talib, M.S., 2014. Conceptual Framework on Halal Food Supply Chain Integrity Enhancement. Procedia - Social and Behavioral Sciences $121(58-67)$ 